\title{
Шлуночкова система головного мозку в постнатальному онтогенезі в чоловіків
}

У ході морфометричного дослідження магнітно-резонансних томограм проаналізовано співвідношення розмірів окремих структур шлуночкової системи в представників чоловічої статі різних вікових періодів. Вивчено гендерні особливості та міжпівкульну асиметрію відповідних показників.

Ключові слова: вентрикулярна система, I період зрілого віку, літній вік, чоловіки, МРТ, морфометрія.

Постановка наукової проблеми та її значення. На сучасному етапі розвитку медичної науки помітно зростає роль фундаментальних дисциплін, у тому числі анатомії людини, медичної та інтегративної антропології [1]. Чим точнішими й достовірнішими стають методи медичної візуалізації, тим актуальнішою стає проблема правильної інтерпретації та стандартизації даних одержуваного зображення $[3,7]$.

Уведення в медичну практику нових методів нейровізуалізації - комп’ютерної та магнітнорезонансної томографії - змінило принципи діагностики морфологічних змін головного мозку й відкрило нові горизонти у вивченні його будови [2].

Характерні анатомічні особливості органів з урахуванням їх індивідуальної мінливості, а також статевих відмінностей досліджені поки що недостатньо. Щодо цього незаслужено мало вивчено індивідуальну мінливість головного мозку людини. Бурхливий розвиток морфології й фізіології нервової системи відволікло увагу дослідників від питань загальної кількісної характеристики мінливості мозку, а це призвело до того, що й по сьогодні в більшості посібників та оглядах наведено суперечливі й неоднорідні дані про вагу головного мозку і його розміри, а особливо вентрикулярну систему [4].

Головний мозок людини володіє значною мінливістю. Він різниться в чоловіків та жінок, у різних рас, етнічних груп. Ознаки відмінностей зберігаються з покоління в покоління й можуть бути важливою характеристикою варіабельності мозку людини як біологічного виду [6].

Водночас практично відсутні роботи із застосуванням класичного методу анатомії - «описувально-вимірювального», тобто роботи з індивідуальної мінливості людей із залученням морфометричних методів із використанням методів варіаційної статистики $[5,8]$.

Недостатньо розроблена проблема індивідуального розвитку головного мозку в постнатальному періоді онтогенезу. Процес розвитку людського організму після народження більше вивчений лише щодо періоду дитинства [4] і мало щодо періодів зрілості та літнього віку.

У зв'язку з цим актуальним $€$ вивчення прижиттєвих морфометричних характеристик, насамперед для вентрикулярної системи головного мозку в людей I періоду зрілого й літнього віку.

Роботу виконано відповідно до основного плану НДР Буковинського державного медичного університету і являє собою фрагмент комплексної міжкафедральної теми «Закономірності перинатальної анатомії та ембріотопографії. Визначення статево-вікових особливостей будови і топографоанатомічних взаємовідношень органів та структур в онтогенезі людини» (№ державної реєстрації 0110U003078).

Мета дослідження - оцінка морфометричних показників вентрикулярної системи головного мозку в представників чоловічої статі за результатами МРT I періоду зрілого та літнього віку.

Матеріал і методи дослідження. Обстеження проводили у відділенні променевої діагностики клінічного закладу «Рівненська обласна клінічна лікарня» на комп’ютерному томографі General Electric Healthcare «Signa MRI 1,5 T» та в кабінеті магнітно-резонансної томографії клінічного закладу «Луцька міська клінічна лікарня» на комп'ютерному томографі Signa Profile Ce Medical Sistem - 1,5 Тл у стандартних анатомічних площинах (сагітальній, фронтальній та аксіальній). Вимірювання проводили в людей без візуальних ознак органічних уражень головного мозку й черепа.

Проаналізовано томограми головного мозку чоловіків різних вікових категорій, а саме: шість томограм (22-35 років) I періоду зрілого віку та 14 томограм літнього віку (61-74 роки).

При порівнянні парних показників (бічних шлуночків) вираховували коефіціснт асиметрії $\left(\mathrm{K}_{\mathrm{acm}}\right)$, який дорівнює різниці між показниками правого й лівого бічних шлуночків, поділеної на суму показників правого та лівого шлуночків, \%.

(C) Комиук T., 2016 
При проведенні статистичних розрахунків використані вбудовані функції MS Excel. Обраховували середню арифметичну та іiі похибку. Порівняння між групами дослідження робили за допомогою непараметричного критерію Мана-Уітні в середовищі програми Exel. Визначено рівень значущості окремих показників відносно відповідних у різні вікові періоди.

Виклад основного матеріалу й обгрунтування отриманих результатів дослідження. Вивчено 13 морфометричних параметрів лікворної системи головного мозку, а саме розміри бічних, III та IV шлуночків головного мозку й довжину водопроводу в осіб чоловічої статі I періоду зрілого та літнього віку. Дані представлено в табл. 1.

Таблиия 1

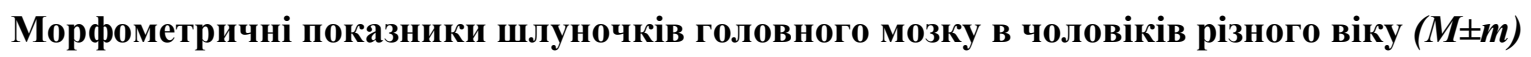

\begin{tabular}{|c|c|c|c|c|}
\hline $\begin{array}{c}\text { № } \\
\text { 3/II }\end{array}$ & $\begin{array}{c}\text { Морфометричний } \\
\text { показник, }, \text { мм }\end{array}$ & & Справа & Зліва \\
\hline \multirow{2}{*}{1} & \multirow{2}{*}{$\begin{array}{l}\text { Довжина переднього рога } \\
\text { бічного шлуночка }\end{array}$} & 3B & $25,7 \pm 1,8$ & $25,4 \pm 2,0$ \\
\hline & & ЛВ & $31,4 \pm 1,8^{*}$ & $31,3 \pm 1,4^{*}$ \\
\hline \multirow{2}{*}{2} & \multirow{2}{*}{$\begin{array}{l}\text { Ширина переднього рога } \\
\text { бічного шлуночка }\end{array}$} & 3B & $6,8 \pm 0,5$ & $6,4 \pm 0,7$ \\
\hline & & ЛВ & $8,4 \pm 0,8^{*}$ & $8,4 \pm 0,7 *$ \\
\hline \multirow{2}{*}{3} & \multirow{2}{*}{$\begin{array}{l}\text { Довжина тіла бічного } \\
\text { шлуночка }\end{array}$} & $3 \mathrm{~B}$ & $43,7 \pm 4,9$ & $41,8 \pm 4,7$ \\
\hline & & ЛВ & $47,5 \pm 2,3$ & $47,5 \pm 1,7$ \\
\hline \multirow{2}{*}{4} & \multirow{2}{*}{$\begin{array}{l}\text { Ширина тіла бічного } \\
\text { шлуночка }\end{array}$} & $3 \mathrm{~B}$ & $10,5 \pm 1,0$ & $11,9 \pm 1,9$ \\
\hline & & ЛВ & $14,6 \pm 0,9^{*}$ & $15,4 \pm 0,9^{*}$ \\
\hline \multirow{2}{*}{5} & \multirow{2}{*}{$\begin{array}{l}\text { Довжина заднього рогу боко- } \\
\text { вого шлуночка }\end{array}$} & 3B & $33,6 \pm 2,2$ & $32,4 \pm 2,6$ \\
\hline & & ЛВ & $34,3 \pm 7,5$ & $39,8 \pm 3,6^{*}$ \\
\hline \multirow{2}{*}{6} & \multirow{2}{*}{$\begin{array}{l}\text { Ширина заднього рогу бічного } \\
\text { шлуночка }\end{array}$} & $3 \mathrm{~B}$ & $9,5 \pm 0,8$ & $8,7 \pm 1,0$ \\
\hline & & ЛВ & $9,6 \pm 1,4$ & $9,4 \pm 1,1$ \\
\hline \multirow{2}{*}{7} & \multirow{2}{*}{\begin{tabular}{|l|} 
Довжина нижнього рогу \\
бічного шлуночка \\
\end{tabular}} & $3 \mathrm{~B}$ & $42,0 \pm 3,0$ & $37,7 \pm 3,8$ \\
\hline & & ЛВ & $46,5 \pm 0,9^{*}$ & $45,7 \pm 0,7^{*}$ \\
\hline \multirow{2}{*}{8} & \multirow{2}{*}{$\begin{array}{l}\text { Передньозадній розмір бічного } \\
\text { шлуночка }\end{array}$} & $3 \mathrm{~B}$ & $85,1 \pm 3,2$ & $81,7 \pm 4,3$ \\
\hline & & ЛВ & $99,3 \pm 1,7^{*}$ & $102,8 \pm 1,8^{*}$ \\
\hline \multirow{2}{*}{9} & \multirow{2}{*}{ Довжина III шлуночка } & $3 \mathrm{~B}$ & $28,3 \pm 3,1$ & \\
\hline & & ЛВ & $30,6 \pm 2,8$ & \\
\hline \multirow{2}{*}{10} & \multirow{2}{*}{ Висота III шлуночка } & 3B & $20,9 \pm 2,9$ & \\
\hline & & ЛВ & $17,3 \pm 0,7$ & \\
\hline \multirow{2}{*}{11} & \multirow{2}{*}{ Довжина водопроводу мозку } & $3 \mathrm{~B}$ & $14,3 \pm 1,5$ & \\
\hline & & ЛВ & $12,2 \pm 0,7$ & \\
\hline \multirow{2}{*}{12} & \multirow{2}{*}{ Довжина IV шлуночка } & $3 \mathrm{~B}$ & $40,5 \pm 2,9$ & \\
\hline & & ЛВ & $36,8 \pm 1,9$ & \\
\hline \multirow{2}{*}{13} & \multirow{2}{*}{ Висота IV шлуночка } & $3 \mathrm{~B}$ & $12,0 \pm 1,2$ & \\
\hline & & ЛВ & & $\pm 1,0$ \\
\hline
\end{tabular}

Примітки. * - Достовірна різниця між чоловіками I періоду зрілого та літнього віку; ЗВ - I період зрілого віку, ЛВ - літній вік.

Аналіз морфометричних показників шлуночків головного мозку, наведених у табл. 1, свідчить про наявність достовірної міжвікової різниці вентрикулярної системи головного мозку та міжпівкульної асиметрії.

Найбільшу мінливість у вивчених нами морфометричних показниках спостерігали під час аналізу бічних шлуночків. Установлено, що довжина й ширина переднього рога бічного шлуночка 
достовірно збільшується 3 віком як справа, так і зліва. Міжпівкульної асиметрії не виявлено. Довжина тіла бічного шлуночка має тенденцію до збільшення з віком у представників чоловічої статі. Ширина тіла бічного шлуночка та довжина заднього рога достовірно збільшуються 3 віком із лівого боку.

Довжина заднього рога бічного шлуночка становила в чоловіків I періоду зрілого віку справа $33,6 \pm 2,2$, а зліва $-32,4 \pm 2,6$ мм $\left(K_{\text {acм }}=1,8\right)$. У чоловіків літнього віку спостерігали асиметрію зі збільшенням довжини заднього рога зліва, порівняно 3 правим $\left(\mathrm{K}_{\mathrm{acm}}=-7,4\right)$.

Простежено міжпівкульну асиметрію довжини тіла бічного шлуночка в чоловіків I періоду зрілого віку зі збільшенням показника справа в чоловіків на $4,3 \%\left(\mathrm{~K}_{\mathrm{acm}}=2,2\right)$. Ширина тіла бічного шлуночка дещо більша зліва в чоловіків I періоду зрілого віку на 11,8 \%.

Довжина нижнього рога достовірно зростає з обох боків до періоду літнього віку. У чоловіків І періоду зрілого віку цей показник збільшений справа на $10,0 \%\left(\mathrm{~K}_{\mathrm{acm}}=5,4\right)$. У чоловіків літнього віку довжина нижнього рога бічного шлуночка більша справа $\left(\mathrm{K}_{\mathrm{acm}}=0,9\right)$.

Передньо-задній розмір бічного шлуночка достовірно зростає з віком у представників чоловічої статі. Цей показник становив у чоловіків I періоду зрілого віку справа $-85,1 \pm 3,2$, зліва $-81,7 \pm 4,3$ мм $\left(K_{\text {aсм}}=2,0\right)$. Виявлено міжпівкульну різницю цього показника в осіб літнього віку зі збільшенням його зліва $\left(\mathrm{K}_{\text {асм }}=-1,7\right)$.

Висота III та IV шлуночків головного мозку, довжина водопроводу мають тенденцію до зменшення 3 віком.

При проведенні дослідження нами встановлено достовірне збільшення розмірів бокових шлуночків із віком у представників чоловічої статі, а саме: довжини й ширини переднього рога бічного шлуночка як справа, так і зліва; ширини тіла бічного шлуночка та довжина заднього рога 3 лівого боку; довжина нижнього рога; передньо-заднього розміру бічного шлуночка.

Виявлено, що висота III та IV шлуночків головного мозку, довжина водопроводу мають тенденцію до поступового зменшення з віком.

Можна припустити, що подібна вікова структурна реорганізація головного мозку зумовлена стійкими метаболічними зрушеннями, що відбуваються в мозку в процесі «старіння» [4].

Висновок. Отже, $є$ підстави вважати, що представлена нами прижиттєва морфометрична характеристика головного мозку людини в різні періоди життя в осіб чоловічої статі та виявлені на їі основі критерії вікової реорганізації головного мозку можуть становити інтерес для фахівців у сфері вікової анатомії, нейрофізіології й нейрохірургії, а для фахівців із МРТ-діагностики виступати еквівалентом анатомічної норми ветрикулярної системи головного мозку.

Перспективи подальших досліджень убачаємо у вивченні залежності параметрів лікворної системи головного мозку людини від форми черепа, типу тілобудови й статі.

\section{Джерала та література}

1. МРТ-морфометрия желудочков головного мозга у пациентов с синдромом дефицита внимания и гиперактивности / В. М. Верхлютов, Г. В. Гапиенко, В. Л. Ушаков [и др.] // Журнал высшей нервной деятельности им. И. П. Павлова. - 2009. - Т. 59, №1. - С. 34-44.

2. Норма при КТ- и МРТ-исследованиях / Торстен Б. Мёллер, Эмиль Райф ; пер. с англ. ; под общ. ред. Г. Е. Труфанова, Н. В. Марченко. - 2-е изд. - М. : МЕДпресс-информ, 2013.- 256 с.

3. Савельева Л. А. Особенности венозного оттока от головного мозга, по данным магнитно-резонансной ангиографии / Л. А. Савельева, А. А. Тулупов // Вестник Новосибирского государственного университета. - Серия : Биология, клиническая медицина. 2009. - Т. 7, вып. 1. - С. 36-40.

4. Серков С. В. МРТ в диагностике расширенных периваскулярных пространств головного мозга (результаты собственных исследований и обзор литературы) / С. В. Серков, И. Н. Пронин, В. Н. Корниенко // Медицинская визуализация. - 2006. - № 5. - С. 10-25.

5. Труфанов Г. Е. МРТ- и КТ-анатомия головного мозга и позвоночника (атлас изображений) : монография / Г. Е. Труфанов. - 2-е изд. - СПБ : Из-во ЭЛБИ-СПб, 2009. - 188 с.

6. A common brain network links development, aging, and vulnerability to disease / G. Douaud, A. R. Groves, C. K. Tamnes [et al.] // Proc Natl. Acad Sci USA. - 2014. - V. 24. - P. 73-78.

7. Association between gait variability and brain ventricle attributes: a brain mapping study / C. Annweiler, M. Montero-Odasso, R. Bartha [et al.] // Exp Gerontol. - 2014. - V. 57. - P. 256-263.

8. New endoscopic route to the temporal horn of the lateral ventricle: surgical simulation and morphometric assessment / J. J. Sánchez, J. Rincon-Torroella, A. Prats-Galino [et al.] // J Neurosurg. - 2014. - V. 121(3). P. 751-759. 
Комшук Татьяна. Желудочковая система головного мозга в постнатальном онтогенезе у мужчин. В ходе морфометрического исследования магнитно-резонансных томограмм проанализировано соотношение размеров отдельных структур желудочковой системы у представителей мужского пола разных возрастных периодов. Изучены гендерные особенности и межполушарная асимметрия соответствующих показателей.

Ключевые слова: желудочковая система, I период зрелого возраста, пожилой возраст, мужчины, МРТ, морфометрия.

Komshuk Tetiana. Ventricular System of the Brain in Postnatal Ontogenesis in Men. Introduction into medical practice of new methods of neuroimaging - computer and magnetic resonance tomography, changed principles of diagnosis of brain morphological changes and opened new horizons in the study of its structure.

The aim of our study was to evaluate morphometric parameters of ventricular system of the brain on the results of MRI of men the period of mature and elderly.

Object and methods. A survey was conducted in the department of radiation diagnosis of clinical institution «Rivne Regional Clinical Hospital» on computer tomograph General Electric Nealthcare «SignaMRI 1,5T» and in the office of magnetic resonance tomography ща clinical institution «Lutsk Clinical Hospital» on computer tomograph Signa Profile Ce Medical Sistem - 1,5 Tl in standard anatomical planes (sagittal, frontal and axial).bMeasurements were carried out in people without visual signs of organic lesions of the brain and skull.

Brain imaging analyzes of men of different age groups, namely six tomograms (22-35 years) I mature period and 14 tomograms of elderly patients (61-74 years).

13 morphometric parameters of cerebrospinal fluid system of the brain were studied, namely the size of lateral, the III and IV brain ventricles and the length of aqueductus cerebri of men of different age groups.

During the study morphometric magnetic resonance tomograms analyzed the size ratio individual structures ventricular system of men of various ages. Studied gender characteristics and interhemispheric asymmetry of relevant indicators.

The study we found a significant increase in the size of the lateral ventricles in the age of men, namely length and width of the anterior horn of the lateral ventricle, both right and left; body width and length of the lateral ventricle posterior horn of the left side; the length of the lower horn; anteroposterior lateral ventricle size.

Found that the height of III and IV ventricles of the brain, the length of water pipe tends to gradually decrease with age.

It can be assumed that this age structural reorganization of the brain are caused by persistent metabolic changes that occur in the brain during the «aging».

Conclusions. Thus, there is reason to believe that presented intravital morphometric characteristic of the man brain of different age persons and identified on this basis criteria of age brain reorganization may be of interest to experts in the field of age anatomy, neurophysiology and neurosurgery, and for specialists of MRI-diagnostic can be an anatomical standard of ventricular system of the brain.

Key words: ventricular system, the man brain of different age, MRI, morphometry.

Стаття надійшла до редколегії 19.02.2016 p.

UDC 59:611.12:796.071

Alona Romaniuk

\section{Special Aspects of Heart rate Variability in Track and Field Athletes and Players}

The article was considered the features of autonomic regulation of heart rate in athletes. Modern level of sporting achievements puts forward the necessary conditions for study and evaluation of functional states and adaptive capacity of all body systems in interconnection, taking into account the autonomic regulation of the heart, the problem is actual enough. In the study were surveyed sportsmen playing sports and track and field athletes, using a method of HRV. It was studied the basic of time, spectral and HRV parameters (in R. Baevskyi) and established the predominant type of of vegetative regulation of cardiac activity. Athletes of team sport were characterized by a decrease in indexes of time than heart rate. he analysis of of spectral indexes has shown increasing values in track and field athletes. It was established predominant type of sympathetic autonomic regulation of the heart in sportsmen playing sports, and the track and field athletes found predominant type of parasympathetic autonomic regulation. Obtained results are confirm lowering mechanisms of self-regulation and activation energy centers metabolic for sportsmen playing sports. In track

(C) Romaniuk A., 2016 